\title{
Urbanization and the Decline of Agricultural Land in Pokhara Sub-metropolitan City, Nepal
}

\author{
Bhagawat Rimal ${ }^{1}$ \\ 1 Specialist/ Urban Development and Land use Change, Everest Geoscience Information Service Center, \\ Kathmandu, Nepal \\ Correspondence: Bhagawat Rimal, Specialist/ Urban Development and Land use Change, Everest Geoscience \\ Information Service Center, Kathmandu, Nepal. E-mail: geonp_2001@yahoo.com
}

\author{
Received: September 10, 2012 Accepted: October 16, 2012 Online Published: December 13, 2012 \\ doi:10.5539/jas.v5n1p54 \\ URL: http://dx.doi.org/10.5539/jas.v5n1p54
}

\begin{abstract}
Pokhara Sub-Metropolitan City is one of the rapidly urbanizing cities of Nepal. This piece of writing analyzes the urbanization trend and transition of cultivated land in Pokhara in the time period of 1977, 1990, 1999 and 2010. Large amount of cultivated land has been transformed into other landuse classes, mainly to urban, in the past 33 years. This paper presents the process of the continuous loss of agricultural land and urban development in Pokhara by utilizing remote sensing and GIS which concludes that urbanization and high population rise as the vital agents behind the loss of farmland of the area. Landsat satellite image have been used for the analysis of land use/land cover change. Supervised image classification has been applied to classify the images to different land use categories. Six land use classes are identified: Urban (Built-up), water body, open field, forest cover, cultivated land and sandy area. Urban and industrial areas are very much enlarged and cultivated and open field area considerably decreased during the study periods 1977 to 2010 . In 1977 , urban area had covered $6.33 \%$ but it increased to $51.42 \%$ in 2010 whereas cultivated land had decreased from $60.73 \%$ to $20.27 \%$ in same period.
\end{abstract}

Keywords: urbanization, cultivated land loss, GIS, Pokhara-Nepal

\section{Introduction}

The last century has experienced dramatic urban expansion. The cities of the third world have been growing at an unprecedented rate. The number of people living in cities in developing countries has at least quadrupled during the second part of the twentieth century. There has been a trend toward the formation of large metropolises or urban agglomerations (WDR, 1999, Waibel, \& Schmidt, 2000). The conversion of agricultural land into urban land uses in the urbanization processes has become a serious issue for sustainable urban development in the developing countries ( $\mathrm{Li} \& \mathrm{Yeh}, 2000)$. Urbanization is a positive outcome of social, economic and political development (Rimal, 2011).

Urbanization is a process of increase of modernization system which modifies the socioeconomic activities and revolutionizes the land use practice according to time frame (Rimal, 2011). Although urbanization is the driving force for modernization, economic growth and development, there is increasing concern about the effects of expanding cities, principally on human health, livelihoods and the environment. The implications of rapid urbanization and demographic trends for employment, food security, water supply, shelter and sanitation, especially the disposal of wastes (solid and liquid) that the cities produce are staggering (UNCED, 1992).

Urban expansion necessarily entails the loss of cultivated lands. How much cultivated land will be consumed by urban expansion and what are the policy implications? Global data on the expansion of cities into cultivated lands are only starting to become available, so the answer to this question at the planetary scale must be exploratory and tentative.... the loss of cultivated lands by 2050 amount to 5.7 percent of the total land under cultivation in 2000 . Some regions can be expected to lose higher shares: Southeast Asia may lose more than 10 percent of its cultivated lands; Western Asia and North Africa, close to 10 percent; South and Central Asia, 8 percent; and East Asia, close to 7 percent. Though these losses could be considered worst-case scenarios, they offer quite realistic orders of magnitude of how much new land will need to be put under cultivation to meet projected food needs. (Angel, 2012). Several studies have investigated the ramifications of exurbanization. The most notable of those studies investigated the effects of exurbanization, concluding that it let to loss of productive agriculture land, open space, 
and wildlife habitat (Platt, 1985; Diamond \& Noonan, 1996; Beatley \& Manning, 1997; Sorensen, Greene, \& Russ, 1997; Riebsame et al., 1994; Rome, 1998; Waldie, 2000; Heimlich \& Anderson, 2001; Theobald, 2002, Shaker \& Ehlinger, 2007). In an era in which the majority of the world population lives in cities, the food and agriculture industries are evermore unsustainable, and urban slums are rapidly expanding, it is becoming crucial that city governments work to ensure food security for their citizens (Gittleman, 2009). Because of the overflow of the mass in the city and the nearby areas, huge cultivated lands, water body, open fields and forest areas have been turning into settlement areas.

Remote sensing techniques can provide information about land cover with a high level of detail as well as high temporal frequency and has already shown their value in mapping urban areas (Herold et al., 2003; Jürgens, 2001 \& 2003; Maktav et al., 2005; Taubenböck et al., 2009 \& 2010). Besides the observation of a status at a particular time, remote sensing provides also the possibility to observe the development of an investigation area by change detection (Lillesand \& Kiefer, 2004). Spatiotemporal analysis using time series of remote sensing data enables the derivation of urban footprints, thus to monitor and quantitatively describe the urban structure and development (Herold et al., 2003; Lucas et al., 2007; Taubenböck et al., 2009 \& 2010). Government agencies, including those involved in urban and regional planning and academic researchers in urban studies have greatly expanded the scope and possibilities for application of GIS to urban issues and problems (Kaplan, Wheeler, \& Hollowey, 2004).

In the last few decades, a substantial growth of urban areas has occurred worldwide. Population increase is one of the most obvious agents responsible for this growth (Araya, Cabral, 2010, ). It is very interesting that the world urban population increase from 0.73 billion (28.8\%) in 1950, 1.51 billion (37.2\%) in 1975, 3.42 billion (50.1\%) in 2009, 4.54 billion (56.6\%) in 2025 and 6.29 billion (69\%) by 2050 (UNDESA, 2010). By the middle of 2009, the number of people living in urban areas, more than $50 \%$ (3.42 billion) had surpassed the number living in rural areas (3.41 billion) and since then the world has become more urban than rural. Northern America, Latin America and the Caribbean, Europe and Oceania are highly urbanized. According to the report 70.2 percent people are living in urban in Oceania, 81.9 percent in Northern America, 79.3 percent in Latin America and the Caribbean, 72.5 in Europe, 41.7 in Asia and 39.6 in Africa respectively. Urbanization is expected to continue rising in both the more developed and the less developed regions so that, by 2050, urban dwellers will likely account for 86 percent of the population in the more developed regions and for 66 percent of that in the less developed regions. According to the expected result, $64.7 \%$ population in Asia and $61.6 \%$ population in Africa will have been settled in urban in 2050 . Similarly, $90.1 \%$ in North America, $88.8 \%$ in Latin America and the Caribbean, $84.3 \%$ in Europe and $74.8 \%$ population in Oceania is expected to be urban by 2050 (UNDESA, 2010).

In 2010, 43\% of the Asia and the Pacific population lived in urban areas, the second lowest urban proportion of a region in the world; however, in the last two decades the Asia-Pacific urban proportion has risen by $29 \%$, more than any other region. However, it has the second fastest urban population growth rate, at an average of $2.0 \%$ per annum (2005-2010). Currently, Africa is the least urbanized region and has the highest urban population growth in the world, at an average annual rate of 3.5\% (2005-2010). Across the Asia-Pacific region, the urban proportion and urban population growth rates vary dramatically (ESCAP, 2011).

In the 18th century, urban centres in Nepal were developed mainly in Kathmandu valley. After the unification of Nepal (1968), Pokhara, Butwal, Tansen, Ilam etc. were emerged as the trade centres outside Kathmandu valley. Most of them were developed at the break-of-bulk points along the Indian and Tibetian trade routes. Consequently, different level of administrative centres developed at the strategic locations and supported for this growth of higher-level urban centres (Blaikie et al, 1982; Poudel, 2008; Rimal, 2011). The number of urban centers in Nepal grew from 10 to 95 between the years 1952/54 and 2011. Central Bureau of Statistics has released the preliminary result of the national population census 2011 on September, according to the statistical report the urban population of Nepal increased from 2.9 percent in 1952/1954 to 17 percent in 2011. Likewise the rural population of Nepal decreased from 86 percent in 2001 to 83 percent in 2011. Only 61 among the 75 districts of the country had municipal areas in 2011, while the urban population increased from 0.23 million to 4.5 million (this increased urban population refers only in terms of the previously declared 58 municipalities), that is an increase by a factor of 19 times in the same period (CBS, 2011). Change in demographic process has large impact on land use change. Fertility, mortality, migration, household structure as well as labour availability play the vital role in land use change and urban development (KC, 2003; Rimal, 2011). Continuous migration from rural areas to urban areas largely contributed to rapid urbanization of Nepal. Urban development has enlarged the modification of natural resources and has changed land use and land cover patterns. Due to the massive urbanization, the dense forests are being barren. The cultivated land is being converted to the jungle of concrete. Industrial sites are distributed irregularly. Due to the access of every infrastructure development and facilities as well as the chances, the attraction of the people towards the city is high. Highly productive areas are commercially plotted into small acres. 
The group on land market buys a large acre of land, plot it into smaller pieces and sell it. The people in the foreign employment also invest upon the land pieces in the city area. The villages are turning bare where as the cities are becoming the massive crowds. High rate of migration, high birth ratio, unbalanced distribution of population are some of the causes of urban population increase. Thus, agricultural land is declining and food scarcity in the near future is predictable. Natural resources are rapidly being destroyed as a result the physical/natural environment has been decaying every day. In Nepal, the dramatic effects of rapid urbanization are very clear in the cities and peri-urban areas. As the cities expand, the main zone of direct impact is the peri-urban area, and those living in the peri-urban interface face many new challenges and opportunities in meeting their needs and accommodating the by-products of the urban populations. In many developing countries, it is rural poverty that drives people from the rural areas into the city in search of economic possibility, food, shelter, advanced life style and education. Several causes are responsible for the urban development of any area. Government plans and policies also promote urbanization process indirectly. Even the categorization of the areas as urban, metropolitan, sub-metropolitan, rural also affects the distribution of facilities and the flow of people. In Nepal, most people move into the urban areas because they are 'pushed' out by factors such as the lack of physical infrastructure, public service accessiblilty, economic opportunity, population growth, land market, globalization, political situation , government plan and policies and tourism activities in the rural areas or because they are 'pulled' into the urban areas by the advantages and opportunities of the city including all public service accessibility. This article has presented the historical urban growth phenomenon, population grwoth and the decay of the agricultural land of Pokhara sub-Metropolitan city.

\section{Method and Materials}

\subsection{Study Area}

Pokhara is a beautiful and historical town of Nepal which was made town municipality in 1962. Designation of Pokhara as the headquarters of the Western Development Region of Nepal in 1972, contributed to upgrade Pokhara municipality in the present status of sub-metropolitan city in 1995 with 18 wards. The sub-metropolitan city shares its border with Lekhnath Municipality, Kahun and Arwa village development committees in the west, Armala, Chhahrepani, Lamachaur and Hemja VDCs in the north and Kristi Nachne Chaur, Nirmal Pokhari and Bharat Pokhari VDCs in the south. Pokhara sub-metropolis lies in the broad valley of Seti River covering an area of 55.31 sq.km (some study shows 56 sq.km ) located on the southern foot of the Mt. Annapurna and Mt. Fishtail Himalayan region $83^{\circ} 58^{\prime} 30^{\prime \prime}$ to $84^{\circ} 02^{\prime} 03^{\prime \prime}$ east longitudes and $28^{\circ} 10^{\prime}$ north to $28^{\circ} 16^{\prime}$ north latitudes. Fewa Lake and Seti River have drained the city. Seti River dissects it into two parts. Enchanting natural beauty and its unique social and cultural heritage are responsible for the present development of town. Pokhara is a remarkable place for natural beauty at an elevation ranges from 627 meter to 980 meter above the sea level. This city is ever known as a real paradise in Earth. Humid sub-tropical monsoon with hot and wet summer and cold and fairly dry winter is found here. The valley is filled with swift flowing river and dotted with clear gleaming lakes. Being the regional headquarters of western region and the second tourist center after Kathmandu; it has attracted a large population from the surrounding areas. It accounts for the highest growth rate of population among the designated towns in the country. The appropriate landscape, suitable topographic condition, favorable climate and the natural beauty fall under physical condition of a place to attract the people towards it. The urban area has the good access of public service which refers to the physical and social infrastructure of any place. Good educational institutions, hospitals governmental offices, diplomatic missions and the important complexes and buildings are centered at the city due to which people shift to these area by leaving the rural villages temporarily or permanently. Pokhara sub-metropolis is selected as the study area because of its rapid process of urbanization and fast change in land uses. 


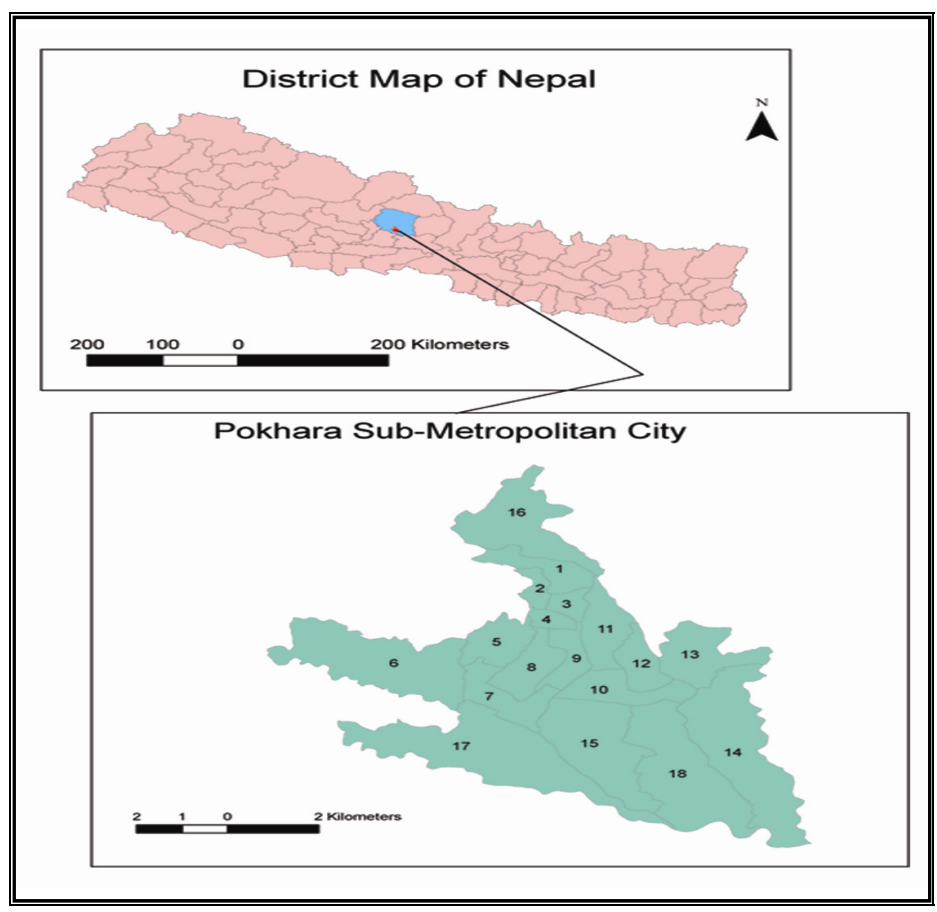

Figure 1. Location map of pokhara

This study includes both field survey and map studies and computer based analysis. In primary session, fieldwork was conducted to acquire first hand data required for the research. Most of the essential data for improving mapping accuracies of spatial changes were collected through the fieldwork. Landscape observations, meetings with experts, and structured interviews were conducted in the sub-Metropolitan area. To analyze the population growth and urban development process, various types of data were collected from publication of Central Bureau of Statistic (CBS), Government offices, and other various websites for the fulfillment of objectives. Fours, pairs of cloud-free Landsat images have been used to classify the study area: Landsat Image 2, Multi Spectral Scanner satellite image (hereafter MSS image with path /row 153/40) March 22, 1977,Landsat Image 5, Thematic Mapper satellite image (hereafter TM image with path/row 142/40) November 10, 1990 and Landsat 7 Enhanced Thematic Mapper (hereafter ETM+ with path/ row 142/40) December 13, 1999 and Landsat Image 5, Thematic Mapper satellite image (hereafter TM image with path/row 142/40) December 3, 2010. All data used in this study were projected to the Universal Transverse Mercator (UTM) projection system that is World Geodetic System 1984.

For this study, land use/land cover maps and topographical maps of the study area were necessary. Possible latest topographic maps of the region were acquired. First, 1977 data are obtained from land use maps the scale of 1:50,000 compiled from ground-verified aerial photographs $(1: 50,000)$ by the Land Resources Mapping Project (LRMP), a collaboration between His Majesty's Government of Nepal (HMGN) and an external consultant (Kenting Earth Sciences Ltd, Ontario, Canada). Topographical map the scale of 1: 25000 has been used for the analysis of images was published by Survey Department, government of Nepal on the dated of 1998 Pokhara. The map is based on the aerial photograph at the scale of 1:50000 taken in 1996.

The IDRISI GIS Taiga version has been used for the analysis of image. According to the land use classification scheme unsupervised and supervised approach with the maximum likelihood parameter (MLP) system was applied to improve the accuracy of the land use classification for the images for all four dates $(1977,1990,1999$ and 2010). In attempting to develop a classification system for use with remote sensing techniques that will provide a framework to satisfy the needs of the majority of users, certain guidelines of criteria for evaluation must first be established (Anderson et al., 1976). The classification system utilized in this study is a slightly modified classification system for remotely sensed data as recommended by Anderson et al. (1976). For simplicity, six types of land use classes: Urban/Built-up, water body, open field, forest cover, cultivated land and sandy area were selected for the study. Classification accuracy assessment is a general term for comparing the classification of geographical data that are assumed to be true to determine the accuracy of the classification process. A total 150 stratified random sampling points were created for the accuracy of classification. The supervised classification 
accuracies of $85.0 \%, 81.08 \%, 83.33 \%$, and $83.88 \%$ were achieved for the years, $1977,1990,1999$ and 2010 respectively.

\section{Result and Discussion}

\subsection{Urbanization trend and Decline of Cultivated land of Pokhara}

In the early period, Pokhara was essentially a market center situated in the broad valley of Seti and its tributaries. Because of the strategic location between mountain and Terai (plain), it became an important staging point between east-west and the Trans-Himalayan trade route (Gurung, 1965; Poudel, 2008; Rimal, 2011). The history of Pokhara city begins with the periodical religious gathering during the medieval period and permanent bazaar (market Places) after the unification of Nepal in 1768. Enchanting natural beauty, tourism activities and its unique social and cultural heritage are responsible for the present development of town Population of Pokhara sub-metropolis. The population is 156312 (census, 2001) with 79563 male and 76749 female and total number of house hold is 37305 . People have been flowing highly in the city area of Pokhara and the valuable farmlands are almost destroyed and used for the settlement. A huge mass in the city consists of the migrants and the immigrants from the rural poor and contribute to the rapidly growing low income which results in adequate financial crisis and famine. Food security, homelessness and poverty, economic instability and low income are some of the consequences of agricultural land declination due to the massive urbanization. The rapid urban development and the decay of agricultural land also results in the population increase, homelessness, food insecurity, low income, environment pollution and climate change. The ratio of local agricultural production has lowered down and the price of such stuffs have been rising very high. Table 1 and figure 2 give the detail information of population distribution of Pokhara sub-metropolitan in 2001.

Table 1. Ward wise population distribution of Pokhara sub- metropolitan city-2001

\begin{tabular}{llllllll}
\hline Ward & Total & Male & Female & Ward & Total & Male & Female \\
\hline 1 & 12037 & 6564 & 5473 & 10 & 12433 & 6107 & 6326 \\
2 & 4859 & 2464 & 2395 & 11 & 7408 & 3669 & 3739 \\
3 & 6962 & 3630 & 3332 & 12 & 7369 & 3501 & 3868 \\
4 & 5988 & 3254 & 3734 & 13 & 6739 & 3078 & 3661 \\
5 & 6829 & 3438 & 3391 & 14 & 2314 & 1154 & 1160 \\
6 & 10663 & 5781 & 4882 & 15 & 10099 & 4883 & 5216 \\
7 & 8241 & 4266 & 3975 & 16 & 10068 & 5117 & 4951 \\
8 & 16112 & 8391 & 7721 & 17 & 12706 & 6343 & 6363 \\
9 & 12111 & 6338 & 5773 & 18 & 3374 & 1585 & 1789 \\
\hline
\end{tabular}

Source: CBS, 2001

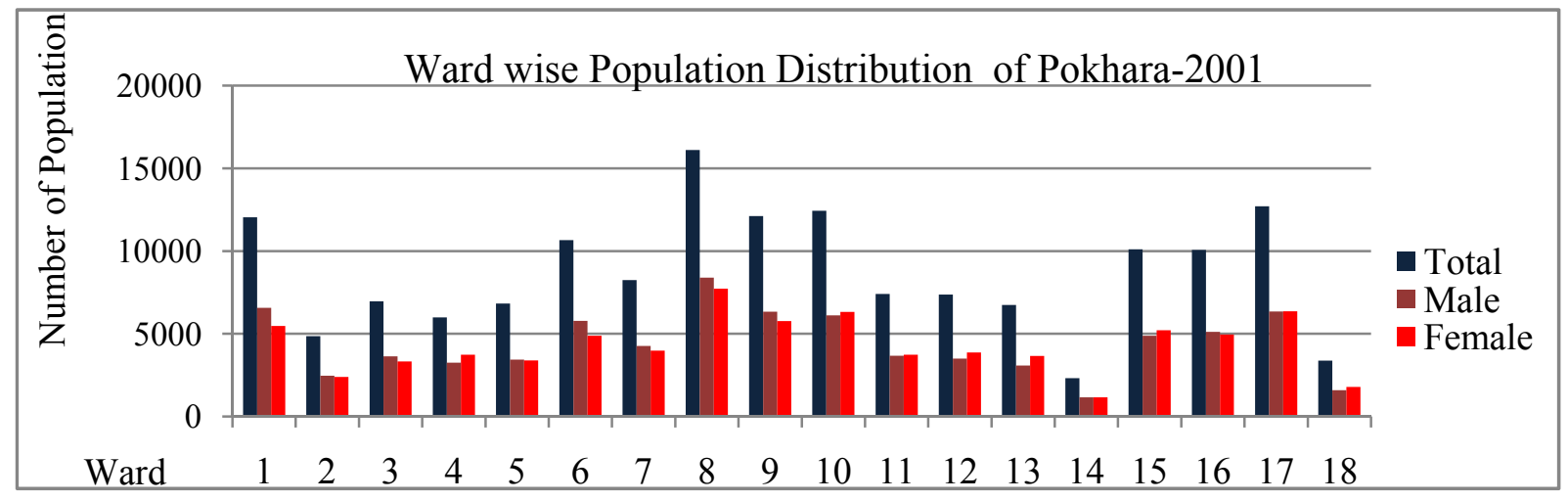

Figure 2. Ward wise population distribution of Pokhara, 2001

The population of Pokhara sub-Metropolitan (Table 2, figure 3) in 1952/54 was 3755, which has increased to 95286 in 1991. In between 1952/54 and 1961, the population increased by 5.36 percent but in 1971, it increased to 
14.30 percent. This high growth rate was mainly due to migration of population from its peripheral villages. Extension of the city area boundary was an equally important factor to increase the urban population. From 1971 to 1981 , the rate of growth of urban population decreased to 8.51 percent. In this inter-census period, the influx of migrants slowed down, however, extension of the city area boundary and natural growth caused to increase the growth rate. In between 1981 and 1991, the growth rate of population accounted for 7.41 percent and its growth rate in between 1991-2001 is 5.6\%. According to the study (UNDP, 2009) the projection of population to 2009 estimated the population of Pokhara to be 232254.

Table 2. Growth of urban population in Pokhara, 1952/54-2001

\begin{tabular}{|c|c|c|c|c|c|}
\hline \multirow[b]{2}{*}{ Year } & \multicolumn{2}{|c|}{ Urban Population of Pokhara } & \multicolumn{3}{|c|}{ Urban Population of Nepal } \\
\hline & Population & $\begin{array}{c}\text { Population Growth } \\
\text { Rate } \%\end{array}$ & $\begin{array}{c}\text { Total } \\
\text { Population }\end{array}$ & $\begin{array}{c}\text { Population Growth } \\
\text { Rate } \%\end{array}$ & $\begin{array}{l}\text { Urban } \\
\text { Center }\end{array}$ \\
\hline $1952 / 54$ & 3755 & - & 238275 & - & 10 \\
\hline 1961 & 5413 & 5.36 & 336222 & 4.40 & 16 \\
\hline 1971 & 20611 & 14.30 & 461938 & 3.21 & 16 \\
\hline 1981 & 46642 & 8.51 & 956721 & 7.55 & 23 \\
\hline 1991 & 95286 & 7.41 & 1695719 & 5.89 & 33 \\
\hline 2001 & 156312 & 5.6 & 3227879 & 6.65 & 58 \\
\hline 2009P & 232254 & & $\begin{array}{c}4525787 \\
\text { (Census, 2011) }\end{array}$ & & 95 \\
\hline
\end{tabular}

Source: CBS 2001, Sharma 2003, Poudel 2008, Rimal, 2011, CBS 2011.

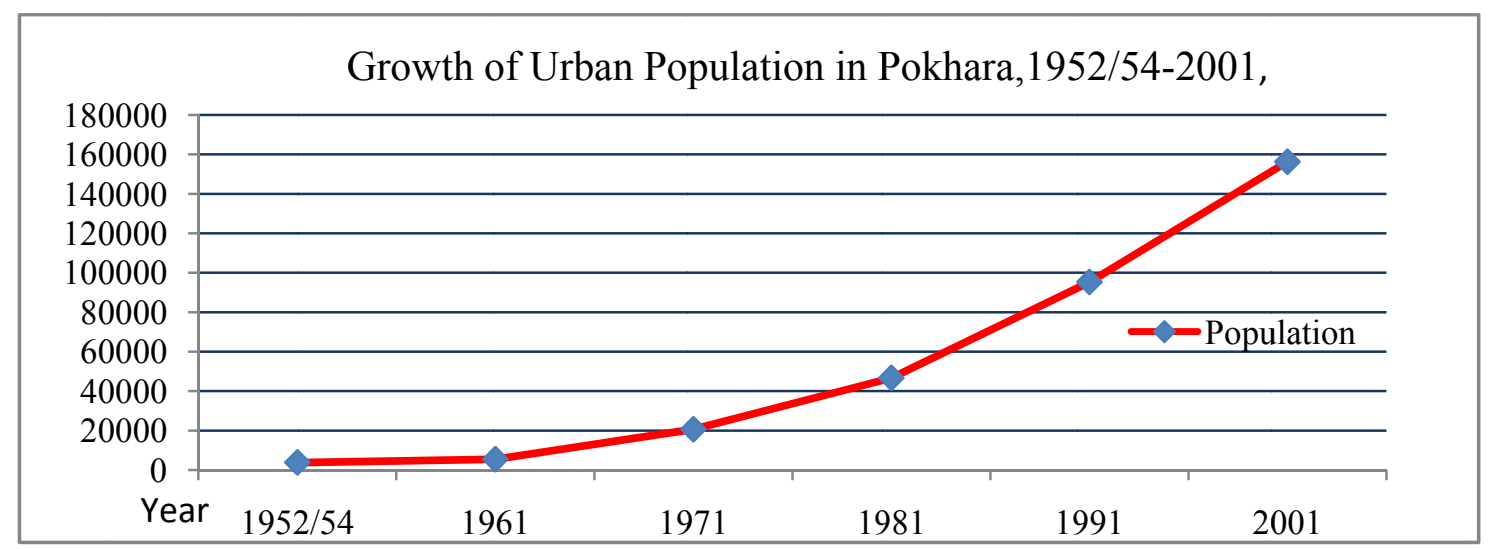

Figure 4. Growth of urban population in Pokhara 1952/54 to 2001

\subsection{Quantify the Magnitude of Land Use/Land Cover Change 1977-2010}

In this chapter, land use /land cover (LULC) change is quantified for the last 33 years in the vicinity of the fast urban growing city of Pokhara using remote sensing and geographic information systems (GIS). The study has analyzed the relationships between population growth and the loss of agricultural land. Thus, research on this subject is important since it shows the relationship between urbanization process and the transition of various landuse classes at different spatial and temporal scales.

Remotely sensed data and ground survey methods were used to evaluate the land cover /land use change between the periods of 1977 to 2010 . According to the study, there has been dramatic change in land use land cover in the city area. From the mention table 3, 4 and figure 4, 5, 6, 7, 8 and 9 of Pokhara, observed that urban area is growing day by day and cultivated land decaling continuously. Table 3 represented the statistical information of land use change in city. Table 4 examines the quantify of land use change, according to study that $24.94 \mathrm{~km} 2(45.09 \%)$ 
urban area has been added in between 1977 to 2010. During the period of 1977 to 1990 urban area has been increased by $7.61 \mathrm{~km}^{2}$ and in the same period $0.88 \mathrm{~km}^{2}$ water body, $3.81 \mathrm{~km}^{2}$ open field, $0.09 \mathrm{~km}^{2}$ forest coverage, $4.41 \mathrm{~km}^{2}$ cultivated land and $0.21 \mathrm{~km}^{2}$ sandy area have been decreased and altered in each other. In the period of 1990 to 1999 urban area has been added by $7.51 \mathrm{~km}^{2}$ areas from other land use classes but in the same time cultivated land has been decreased by $7.78 \mathrm{~km}^{2}$ areas. Meanwhile, water area has been transformed and decreased by $0.71 \mathrm{Km}^{2}(1.24 \%)$ in between 1977 to 2010 . Likewise, $2.20 \mathrm{~km}^{2}(3.98 \%)$ open field has been changed in other land use class in between 1977-2010. Analysis examines that, water body, forest cover, sandy area have been changed in minor ratio but cultivated land and open field decreased drastically and increased of urban area radically.

Table 3. Land use statistic of Pokhara sub metropolitan city 1977-2010

\begin{tabular}{lcccccccc}
\hline Years & \multicolumn{2}{c}{1977} & \multicolumn{2}{c}{$\mathbf{1 9 9 0}$} & \multicolumn{2}{c}{$\mathbf{1 9 9 9}$} & \multicolumn{2}{c}{$\mathbf{2 0 1 0}$} \\
\hline Land use type & $\mathrm{Km}^{2}$ & $\%$ & $\mathrm{Km}^{2}$ & $\%$ & $\mathrm{Km}^{2}$ & $\%$ & $\mathrm{Km}^{2}$ & $\%$ \\
Urban/ Builtup & 3.50 & 6.33 & 11.11 & 20.08 & 18.62 & 33.66 & 28.44 & 51.42 \\
Water Body & 7.73 & 13.97 & 6.85 & 12.38 & 7.10 & 12.84 & 7.02 & 12.69 \\
Open field & 6.46 & 11.68 & 4.44 & 8.03 & 3.53 & 6.38 & 4.26 & 7.70 \\
Forest Cover & 0.84 & 1.52 & 0.75 & 1.36 & 0.87 & 1.57 & 1.22 & 2.21 \\
Cultivated Land & 33.59 & 60.73 & 29.18 & 52.76 & 21.40 & 38.70 & 11.21 & 20.27 \\
Sandy Area & 3.19 & 5.77 & 2.98 & 5.39 & 3.79 & 6.85 & 3.16 & 5.71 \\
Total & 55.31 & 100 & 55.31 & 100 & 55.31 & 100 & 55.31 & 100 \\
\hline
\end{tabular}

Table 4. Quantify the magnitude of land use/land cover change 1977-2010

\begin{tabular}{lccccccccc}
\hline & \multicolumn{3}{c}{ Land cover Area in $\mathrm{Km}^{2}$} & \multicolumn{3}{c}{ Magnitude in $\mathrm{Km}^{2}$} & $\begin{array}{c}\text { Total change } \\
\text { in } \mathrm{Km}^{2}\end{array}$ & $\begin{array}{c}\text { Total } \\
\text { change in \% }\end{array}$ \\
\hline Land use type & $\mathbf{1 9 7 7}$ & $\mathbf{1 9 9 0}$ & $\mathbf{1 9 9 9}$ & $\mathbf{2 0 1 0}$ & $\mathbf{1 9 7 7 -}$ & $\mathbf{1 9 9 0 -}$ & $\mathbf{1 9 9 9 -}$ & $\mathbf{1 9 7 7 -}$ & $\mathbf{1 9 7 7 -}$ \\
Urban & 3.50 & 11.11 & 18.62 & 28.44 & +7.61 & +7.51 & +9.82 & +24.94 & +45.09 \\
Water Body & 7.73 & 6.85 & 7.10 & 7.02 & -0.88 & +0.25 & -0.08 & -0.71 & -1.28 \\
Open Field & 6.46 & 4.44 & 3.53 & 4.26 & -3.81 & -0.91 & +0.73 & -2.20 & -3.98 \\
Forest Cover & 0.84 & 0.75 & 0.87 & 1.22 & -0.09 & +0.12 & +0.35 & +0.38 & +0.68 \\
Cultivated & 33.59 & 29.18 & 21.40 & 11.21 & -4.41 & -7.78 & -10.19 & -22.38 & -40.46 \\
Land & 3.19 & 2.98 & 3.79 & 3.16 & -0.21 & +0.81 & -0.63 & -0.03 & 0.60 \\
Sandy & & & & & & & & & $\mathbf{2 0 1 0}$ \\
\hline
\end{tabular}

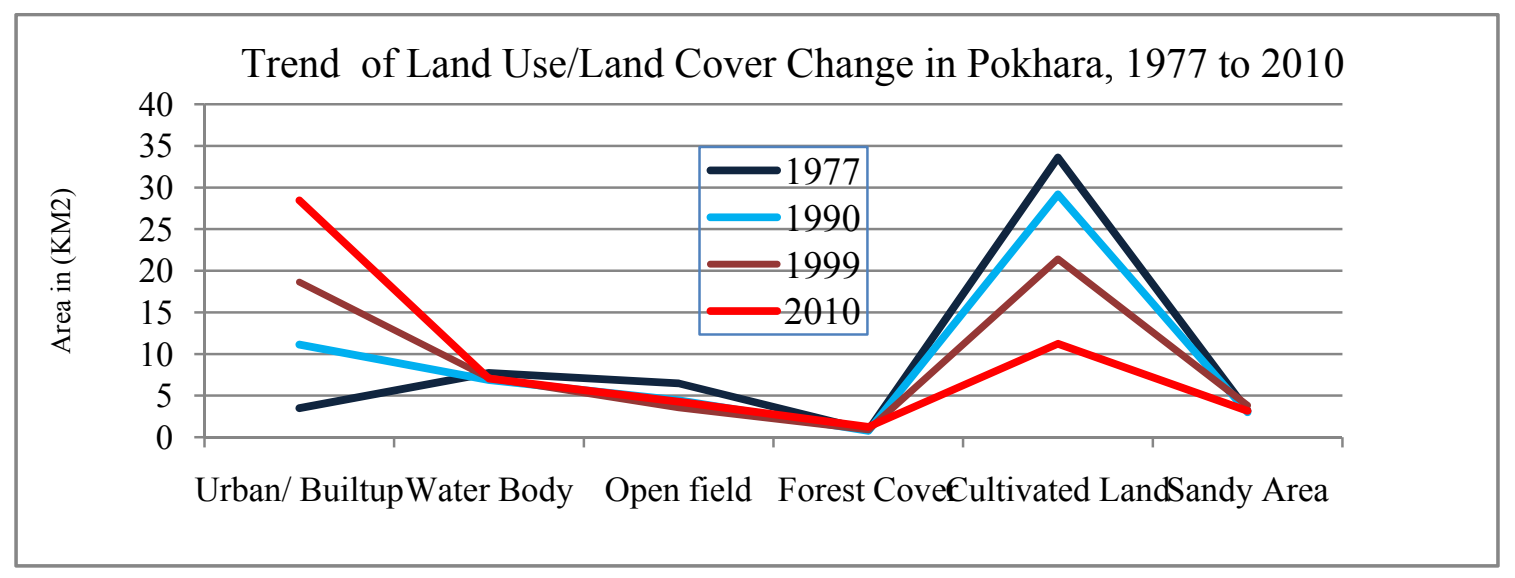

Figure 4. Trend of land use change in Pokhara, 1977-2010 


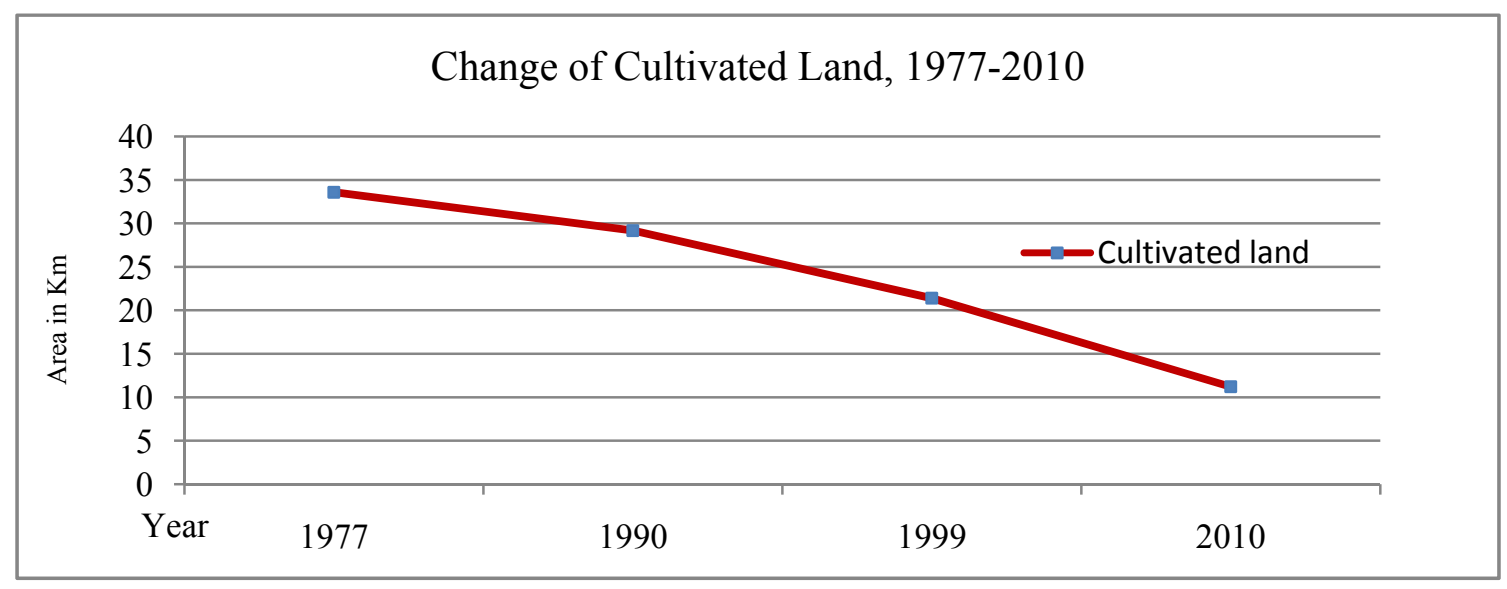

Figure 5: Change of Cultivated land, 1977-2010

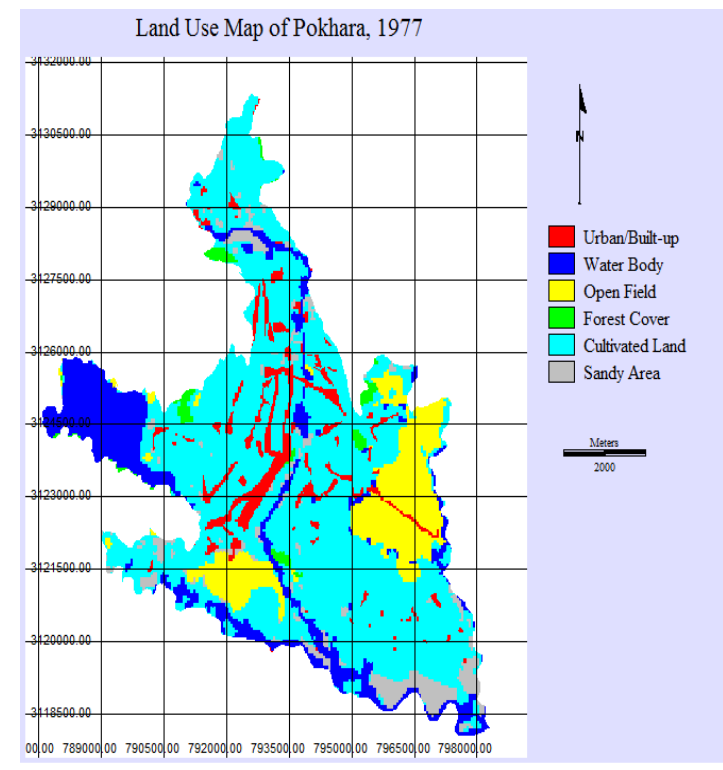

Figure 6. Land use map of Pokhara, 1977

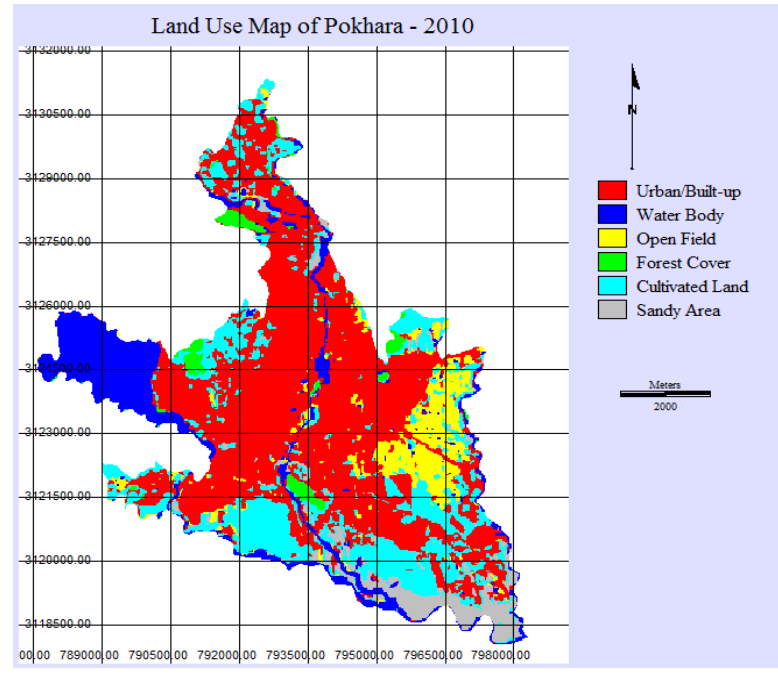

Figure 8. Land use map of Pokhara, 1999

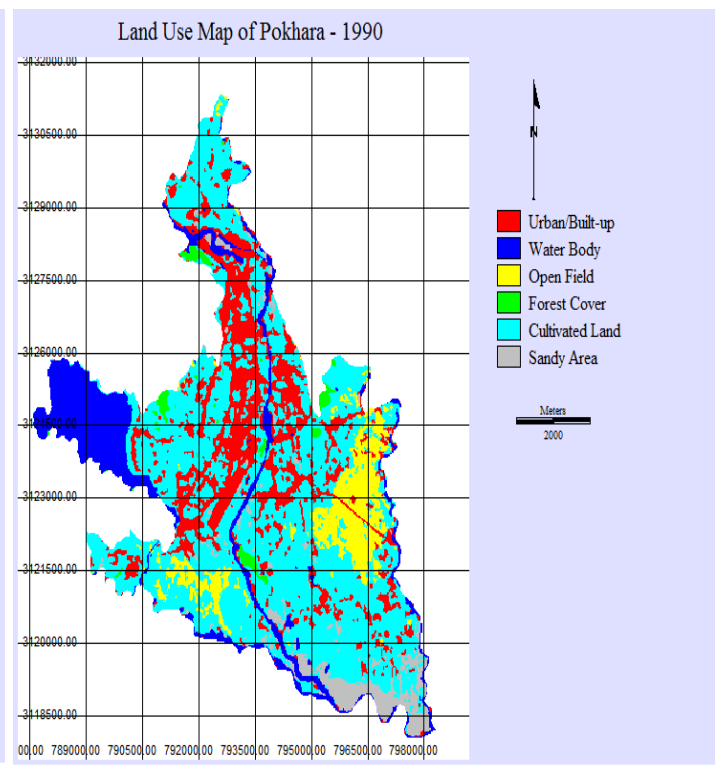

Figure 7. Land use map of Pokhara, 1990

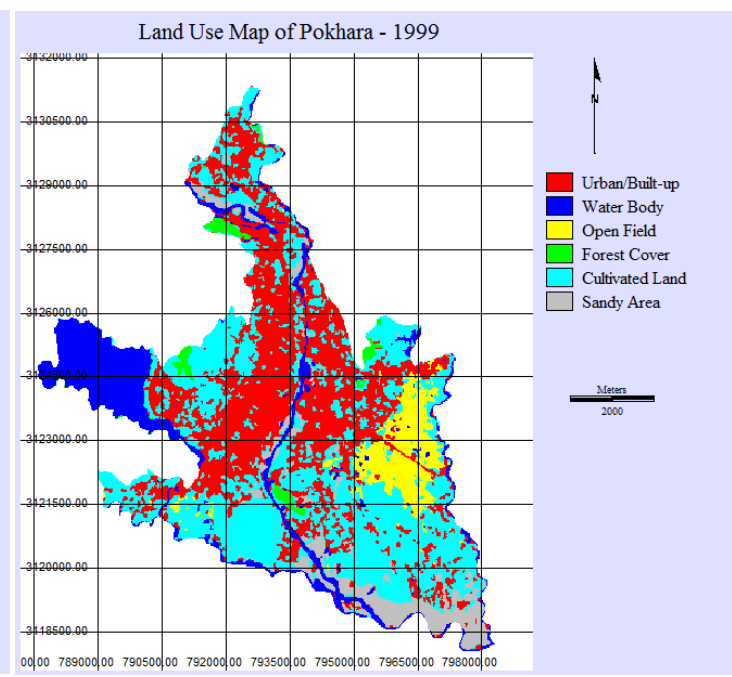

Figure 9. Land use map of Pokhara, 2010 


\subsubsection{Land Use Change in Pokhara, 1977-1990}

According to the transition table 5, all land cover classes have been transformed in each other land cover classes; $0.04 \mathrm{Km}^{2}$ urban area has been converted into water, $0.05 \mathrm{~km}^{2}$ in open field, $0.41 \mathrm{~km}^{2}$ in cultivated land and 0.05 $\mathrm{km}^{2}$ in sandy area in between 1977 to 1990 . Water body has been converted into urban, open field, forest, cultivated land and sandy area. It transformed $0.09 \mathrm{~km}^{2}$ into water, $0.01 \mathrm{~km}^{2}$ into forest, $2.25 \mathrm{~km}^{2}$ into cultivated land and $0.08 \mathrm{~km}^{2}$ in sandy area respectively. Similarly, $6.99 \mathrm{~km}^{2}$ cultivated land converted into urban, $1.02 \mathrm{~km}^{2}$ into water, $0.57 \mathrm{~km}^{2}$ in open field, $0.24 \mathrm{~km}^{2}$ in forest and $1.17 \mathrm{~km}^{2}$ in sandy area. Likewise, $0.30 \mathrm{~km}^{2}$ sandy areas transformed in urban, $0.24 \mathrm{~km}^{2}$ in water, $0.04 \mathrm{~km}^{2}$ in open field and $1.47 \mathrm{~km}^{2}$ in cultivated land respectively.

Table 5. Land use transition in $\mathrm{km}^{2}(1977-1990)$

\begin{tabular}{lllllllll}
\hline Year & & \multicolumn{9}{c}{$1990 \mathrm{Km}^{2}$} & Total \\
\hline \multirow{4}{*}{$1977 \mathrm{Km}^{2}$} & Urban & Water & Open Field & Forest & Cultivated & Sandy & \\
& Urban & 2.95 & 0.04 & 0.05 & 00 & 0.41 & 0.05 & 3.50 \\
& Water & 0.44 & 5.39 & 0.12 & 0.01 & 1.21 & 0.56 & 7.73 \\
& Open & 0.36 & 0.09 & 3.66 & 0.01 & 2.25 & 0.08 & 6.46 \\
& Forest & 0.03 & 0.07 & 00 & 0.49 & 0.24 & 00 & 0.84 \\
& Cultivated & 6.99 & 1.02 & 0.57 & 0.24 & 23.60 & 1.17 & 33.59 \\
& Sandy & 0.30 & 0.24 & 0.04 & 0.00 & 1.47 & 1.12 & 3.17 \\
Total & & 11.11 & 6.85 & 4.44 & 0.75 & 29.18 & 2.98 & 55.31 \\
\hline
\end{tabular}

\subsubsection{Land use change in Pokhara, 1990-1999}

Mentioned transition table 6 (1990-1999) shows that urban area developed from various other land use classes. Due to the sufficient public accessibility, more people are attracted in Pokhara. During this period, $0.27 \mathrm{~km}^{2}$ urban areas changed into water body, $0.17 \mathrm{~km}^{2}$ area has been transformed into open field, $0.03 \mathrm{~km}^{2}$ area converted into forest, $2.05 \mathrm{~km}^{2}$ in cultivated and $0.14 \mathrm{~km}^{2}$ in sandy area. In the same period, $0.37 \mathrm{~km}^{2}$ area converted into urban from water body. Water body and forest cover area have been changed in minor ratio. Open field has converted into urban by $0.37 \mathrm{~km}^{2}$. Likewise open area has been converted into water by $0.08 \mathrm{~km}^{2}$ and it transformed $1.38 \mathrm{~km}^{2}$ in cultivated land. But $9.19 \mathrm{~km}^{2}$ cultivated land transformed into urban land alone, $0.62 \mathrm{~km}^{2}$ altered in water, 0.72 $\mathrm{km}^{2}$ in open field, 0.21 in forest and $1.46 \mathrm{~km}^{2}$ in sandy area in 1990 to 1999 . Sandy area declined and changed into other land use classes whereas $2.02 \mathrm{~km}^{2}$ area remained as it was.

Table 6. Land use transition in $\mathrm{km}^{2}(1990-1999)$

\begin{tabular}{lllllllll}
\hline Year & & \multicolumn{9}{c}{$1999 \mathrm{Km}^{2}$} & Total \\
\hline \multirow{4}{*}{1990} & Urban & 8.44 & 0.27 & 0.17 & 0.03 & 2.05 & 0.14 & 11.11 \\
$\mathrm{Km}^{2}$ & Water & 0.37 & 6.00 & 0.00 & 0.04 & 0.28 & 0.17 & 6.86 \\
& Open & 0.37 & 0.08 & 2.61 & 00 & 1.38 & 0.00 & 4.44 \\
& Forest & 0.02 & 0.03 & 00 & 0.59 & 0.11 & 0.00 & 0.75 \\
& Cultivated & 9.19 & 0.62 & 0.72 & 0.21 & 16.98 & 1.46 & 29.18 \\
& Sandy & 0.23 & 0.10 & 0.03 & 00 & 0.60 & 2.02 & 2.98 \\
Total & & 18.62 & 7.10 & 3.53 & 0.87 & 21.40 & 3.79 & 55.31 \\
\hline
\end{tabular}

3.2.3 Land use change in Pokhara, 1999-2010

According to the transition table 7, urban area has been increased and it covered more territory than other land use classes. From the cross analysis, we can observe that $0.36 \mathrm{Km}^{2}$ urban area transformed into water, $0.45 \mathrm{~km}^{2}$ urban area has been altered in open field, $0.05 \mathrm{~km}^{2}$ urban area has been converted into forest, $0.92 \mathrm{~km}^{2}$ area has been converted in cultivated land and $0.18 \mathrm{~km}^{2}$ in sandy area. In the mean time, $0.59 \mathrm{~km}^{2}$ water body was converted into 
urban area, $0.20 \mathrm{~km}^{2}$ in open field, $0.09 \mathrm{~km}^{2}$ in forest, 0.17 in cultivated land and $0.14 \mathrm{~km}^{2}$ in sandy area. Since the constant portion of Phewa lake is located in the Pokhara city, the transition on water body cannot be observed as such. In the mean time, $10.05 \mathrm{~km}^{2}$ cultivated land has been transformed into urban, $0.44 \mathrm{~km}^{2}$ in water body 0.96 $\mathrm{km}^{2}$ area in open field, $0.27 \mathrm{~km}^{2}$ in forest coverage and 0.60 in sandy area. According to the analysis, more than 10 $\mathrm{km}^{2}$ urban has been increased and same portion of cultivated land decreased in this period. Political movement and public security are the two main driving factor of urban development of these ten years. Pokhara has become high destination of tourism activities in present year. Development of tourism industry is another attraction factor of people from outer part of the city.

Table 7. Land use transition in $\mathrm{Km}^{2}$ (1999-2010)

\begin{tabular}{llllllllll}
\hline Year & & \multicolumn{9}{c}{$2010 \mathrm{Km}^{2}$} & & Total \\
\hline \multirow{4}{*}{1999} & $\mathrm{Km}^{2}$ & Urban & Water & Open Field & Forest & Cultivated & Sandy & \\
\cline { 3 - 8 } & & 16.65 & 0.36 & 0.45 & 0.05 & 0.92 & 0.18 & 18.61 \\
& & 0.59 & 5.91 & 0.20 & 0.09 & 0.17 & 0.14 & 7.10 \\
& Open & 0.49 & 0.07 & 2.53 & 00 & 0.40 & 0.03 & 3.53 \\
& Forest & 0.02 & 0.02 & 00 & 0.80 & 0.03 & 00 & 0.87 \\
& Cultivated & 10.05 & 0.44 & 0.96 & 0.27 & 9.10 & 0.60 & 21.40 \\
\multirow{3}{*}{ Total } & Sandy & 0.64 & 0.22 & 0.12 & 0.00 & 0.60 & 2.21 & 3.79 \\
& & 28.44 & 7.02 & 4.26 & 1.21 & 11.22 & 3.16 & 55.31 \\
\hline
\end{tabular}

\section{Conclusion}

In this article, an integrated approach combining remote sensing and GIS techniques was applied to quantitatively characterize the patterns of land use and cover change (LULC) and examine the relationship between urban population growth, land use dynamics and the transition of farmland to the urban built up since 1977 to 2010 . The use of remotely sensed data showed that Pokhara has had a significant change in land use cover over the last 33 years and high rise of the settlement field. In course of the research of the fast growing city of western Nepal, Pokhara, urban/Built-up, water body, open field, forest cover, cultivated land and sandy area were found the pattern of land use land cover change from the images of 1977,1990, 1999 and 2010. Central part of city area has dense settlement and western part of city area covered by beautiful Lake Phewa. Likewise, open field area is located in eastern part of city which is purposed for the new airport. Dramatic changes in land use and land cover have occurred, with loss of open field and cropland to urban use. The people from the rural areas and the nearby districts shift to the urban centers for the various reasons. As a result, the settlement of the core and the periphery areas of urban gets thickened. People center themselves in such areas and the cultivated land in the city areas converts to the urban builtup in no years. Population in the city area is growing rapidly. The villages are turning bare where as the cities is becoming the massive crowd. High rate of migration, high birth ratio, unbalanced distribution of population are some of the causes of population increase. Not only the city but also the nearby area starts getting urbanized. It causes land use and land cover change and the decay of farmland.

The attraction of people towards the urban area is high and the ratio of land use and land cover change is increasing every day. Urbanization is based mainly in the social development with the specification and characteristics in the specific subject matters such as physical infrastructure development, economic and commercial development which directly contribute to the loss of cultivated land.

To cope up the food demand of the urban area, there is the alarming need of the balance between the urbanization and the proper consumption of the cultivated area. We need to utilize the uncultivated and undercultivating areas to the fullest. The fertile barren lands need to be explored out for the cultivation and the unfertile area should be developed for the settlement. In order to rise the living standard of the people along with the reduction of poverty, the well managed urbanization process and the urban agriculture is essential. For the sustainable development and food security, the government needs to make the intensive study in the collaboration with the national economists, geograpers, planners and the government officials. Protection measures, more strict urban plans and policies are essential for the protection of the arable land and well managed urbanization process. The decentralized plans and policies, rural area development package programmes, well managed urban settlement etc can be some helpful 
concepts to assist in managing the urbanization. In terms of physical infrastructure development of the city area, fixed scientific measures should be strictly brought into action. So, it is wise to declare the unproductive and bare areas as the industrial and utilize the productive land for harvesting. Similarly, certain areas should be marked as the residential areas with the proper access of the basic daily needs. Declaring any city or place alone cannot assist in improving the condition but the empowerment of the rural areas through the local governance and good governance, remote areas can be brought into the mainstream of development which also supports in controlling the flow of migrants to the urban areas. The criteria of being urban should be modified. The need of providing the basic needs and requirements and uplifting the miserable situation of the urban areas is of most importance.

\section{References}

Anderson, J. R., Hardy, E. E., Roach, J. T., \& Witmer, R. E. (1976). A Land Use and Land Cover Classification System for Use with Remote Sensor Data Geological Survey Professional Paper. No. 964, Government Printing Office, Washington, D.C.

Angel Solly. (2012). Urban Expansion and Cultivated Land, Urbanization Project.

Araya, Y. H., \& Cabral, P. (2010). Analysis and Modeling of Urban Land Cover Change in Setúbal and Sesimbra, Portugal, Remote Sensing, 2, 1549-1563. http://dx.doi.org/10.3390/rs2061549

Balkumar, K. C. (2003). Internal migration in Nepal. In Population Monograph of Nepal. Central Bureau of Statistics, Kathmandu, 2, 121-168.

Beatley, T., \& Manning, K. (1997). The ecology of place: planning for environment,economy, and commnity. Washington, D. C.: Island Press.

Blaikie, P., John, C., \& David, S. (1982). Nepal in Crisis. New Delhi: Oxford University Press.

CBS (Central Bureau of Statistics). (2011). Preliminari Result of Netional Population Census. Government of Nepal, Central Bureau of Statistics, Kathmandu, Nepal.

Diamond, H. L., \& Noonan, P. F. (1996). Land use in America. Washington, D. C.: Island Press.

ESCAP (Economic and Social Commission for Asia and the Pacific). (2011). Statistical Yearbook for Asia andthe Pacific.

Gittleman, M. (2009). Urban Expansion in Addis Ababa: Effects of the Decline of Urban Agriculture on Livelihood and Food Security. Sustainable, 1-16.

Gurung, H. B. (1965). Pokhara Valley, Nepal Himalay: A Field Study in Regional Geography.

Heimlich, R. E., \& Anderson, W. D. (2001). Development at the urban fringe and Beyond: impacts onagricultureand rural land. Agricultural Economic Report No. 803. Washington, D. C.: U.S. Department of Agriculture, Economic Research Service. http://dx.doi.org/10.1016/S0034-4257(03)00075-0

Herold, M., Goldstein, N. C., Clarke, K. C. (2003). The spatiotemporal form of urban growth: measurement, analysis and modeling. Remote Sensing of Environment, 86, 286-302.

Jürgens, C. (2001). Remote Sensing of Urban Areas - Fernerkundung in urbanen Räumen. In Proceedings (Abstracts and Full papers on Supplement CD-ROM) of the 2nd International Symposium (Vol. 35). Regensburger Geographische Schriften, Regensburg.

Jürgens, C. (2003). Remote Sensing of Urban Areas. Proceedings of the 4th International Symposium, The International Archives of Photogrammetry, Remote Sensing and Spatial Information Sciences, 34.

Kaplan, D. H., Wheeler, J. O., \& Hollowey, S. R. (2004). Urban Geography. New York: John Wileyand Sons.

Li, X., \& Yeh, A. G. O. (2000). Modelling sustainable urban development by the integration of constrained cellular automata and GIS. International Journal of Geographical Information Science, 14(2), $131-152$. http://dx.doi.org/10.1080/136588100240886

Lillesand, T. M., Kiefer, R. W., \& Chipman, J. W. (2004). Remote Sensing and Image Interpretation (5th Edition), New York.

Lucas, R., Rowlands, A., Brown, A., Keyworth, S., Bunting, P. (2007). Rule-based classification of multi temporal satellite imagery for habitat and agricultural land cover mapping. ISPRS Journal of Photogrammetry \& Remote Sensing, 62, 165-185. http://dx.doi.org/10.1016/j.isprsjprs.2007.03.003

Maktav, D., Erbek, F. S., \& Jürgens, C. (2005). Remote Sensing of Urban Areas. International Journal of Remote Sensing, 26(4), 655-659. http://dx.doi.org/10.1080/01431160512331316469 
Platt, R. H. (1985). The farmland conversion debate: NALs and beyond. Professional Geographer, 37(4), 433-442. http://dx.doi.org/10.1111/j.0033-0124.1985.00433.x

Poudel, K. R. (2008). Urban Growth and Land Use Change in the Himalaya Region A Case Study of Pokhara Sub-Metropolitan City, Nepal. GIS Ostrava, 27, 1-11.

Riebsame, W. E., Parton, W. J., Galvin, K. A., Burke, I. C., Bohren, L., Young, R., \& Knop, E. (1994). Integrated modeling of land use and cover change. Bioscience, 44, 350-356. http://dx.doi.org/10.2307/1312385

Rimal, B. (2011). Urban Development and Land use Change of Main Nepalese Cities. Ph.D thesis. Submitted to the Faculty of Earth Science and Environmental Management, University of Wroclaw (Unpublished)

Rome, A. W. (1998). William Whyte, open space, and environmental activism. Geographic Review, 88(2), 259-274. http://dx.doi.org/10.2307/215804

Shaker, R., \& Ehlinger, T. J. (2007). Agricultural Land Fragmentation and Biological Integrity: The Impacts of a Rapidly Changing Landscape on Streams in Sutheastern Wisconsin (pp. 1-50). Technical Report, Fish Ecology Laboratory, University of Wisconsin-Milwaukee, Milwaukee, WI 53201.

Sorensen, A. A., Greene, R. P., \& Russ, K. (1997). Farming on the edge. Washington, D.C.: American Farmland Trust: DeKalb: Northern Illinois University, Center for Agriculture in the Environment.

Taubenböck, H., Clodt, S., Wurm, M., Wegmann, M., \& Jürgens, C. (2010). The capabilities $\quad$ of remote sensing to derive urban location factors for probability-based spatial growth analysis, Reviewed from . http://www.corp.at

Taubenböck, H., Wegmann, M., Roth, A., Mehl, H., \& Dech, S. (2009). Urbanization in India Spatiotemporal analysis using remote sensing data. Computers, Environment and Urban Systems, 33, 179-188. http://dx.doi.org/10.1016/j.compenvurbsys.2008.09.003

Theobald, D. M. (2002). Land-use dynamics beyond the American urban fringe. The Geographical Review, 91(3), 544-564.

UNCED (United Nations Conference on Environment and Development). (1992). Agenda 21, Rio de Janeiro.

UNDESA (United Nation Department of Economic and Social Affairs). (2010). World Urbanization Prospects, The 2009 Revision

UNDP ( United Nation Development Project). (2009). Earthquake Risk Reduction and Recovery Preparedness Programme for Nepal. Report on Impact of Settlement Pattern, LandUse Practice and Options in High Risk Areas, Pokhara Sub-Metropolitan City.

Waibel, H., \& Schmidt, E. (2000) Feeding Asian Cities: Food Production and Processing Issues Paper presented at the City Net, AFMA, FAO Regional Seminar Bangkok, 27-30 November.

Waldie, D. J. (2000). Do the voters really hate sprawl? New York Times (Late edition, Final), 3 march, A, 21.

WDR (World Development Report). (1999). Defines cities and urban areas as concentrations of non agricultural workers and non-agricultural production sectors. 